\title{
Factors Affecting the Adoption of Yam Storage Technologies in the Northern Ecological Zone of Edo State, Nigeria
}

\author{
D. U. Okoedo-Okojie and E.A. Onemolease
}

\author{
Department of Agricultural Economics \& Extension, Faculty of Agriculture, Ambrose Alli \\ University, PMB 14, Ekpoma, Edo State, Nigeria
}

KEYWORDS Adoption. Yam. Storage. Technologies. Nigeria

\begin{abstract}
The study examined the factors affecting the adoption of modern yam storage technologies by farmers in the northern ecological zone of Edo State, Nigeria. Data were collected from 127 respondents and analysed with frequency tables and logistic regression. Data analysis reveals yam barn to be the major traditional storage method used by farmers $(100 \%)$. Their adoption of improved yam storage technologies was low with shelving being the most widely adopted $(28.3 \%)$. Logistic regression analysis indicates that age (odd ratio $=0.67$ ), farm size (3.68), farming experience (1.25) and contact with extension agents (1.79) had significant $(\mathrm{p}<0.05)$ influence on farmers' adoption of improved yam storage technology. Major constraints limiting the farmers' adoption of these technologies were ignorance of technology existence $(100 \%)$, non-availability $(46.5 \%)$ and high cost $(34.6 \%)$ of the some of the storage technologies. Farmers should be provided with information regarding improved storage methods as well as exposed to training on their use.
\end{abstract}

\section{INTRODUCTION}

Post-harvest storage losses have been of concern even to the United Nations which brought it to international focus when it declared in 1975 that "further reduction of post-harvest food losses in developing countries should be undertaken as a matter of priority" (FAO and UNEP 1981). This led many national governments to take more seriously the problems of storage of agricultural produce. Although attempts have been made to increase agricultural production by bringing more land into cultivation and use of improved seeds and chemicals, these have been less effective because any apparent gain in production has been lost from the moment the food crop is harvested to the time it reaches the consumers' table (Oracca-Tetteh 1978).

Post-harvest food losses are one of the important sources of food insecurity in Africa. According to AMCOST (2006), pre- and postharvest food crop loss among African countries is estimated at about $10 \%$, which is higher than the global average. Although it has been difficult to quantify post-harvest storage losses, some claim that as much as $20 \%$ of yam tubers may be

Address correspondence to:

E.A. Onemolease,

Department of Agricultural Economics \& Extension

Faculty of Agriculture, Ambrose Alli University

PMB 14, Ekpoma, Edo state, Nigeria

E-mail: onemolease@yahoo.com lost to pest attack in storage (Sauphanor and Ratnadass 1985 cited by FAO 1998). Tropical root and tuber crops such as cassava, yam, and cocoyam are important household food security and income generating crops in many African countries (AMCOST 2006; FAO 1998), and over 5 million people are said to depend on these crops for food, feeds and income. Thus, losses associated with these crops limit the potential income of the farmers, threatens food security and exacerbates conditions of poverty among rural households, whose income stream depends on the ability to store excess farm produce for a later date (Ntiokwana 1999 cited by ThamagaChitja et al. 2004).

Although farmers have been known to practice indigenous storage of farm produce, these have been known to be less effective compared to modern storage methods. According to Mughogho (1989), Omoruyi and Orhue (1991) and Tyler (1982), produce stored under the traditional system usually do not keep long and farmers usually suffer great losses. Thus, there is need for the extension service to actively pursue and communicate knowledge of improved storage methods to farmers since effective storage plays an important role in stabilising food supply at the household level by smoothing the seasonal food production.

For storage to be effective, crop losses must be minimised (Takavarasha and Rukovo 1989). Improved methods of storage have therefore been 
developed which attempt to minimize crop losses and reduce the causes of post-harvest deterioration of yam tubers (Ezeike 1995; Fiagan 1995). The agricultural extension service in Nigeria and in Edo State particularly has disseminated and encouraged farmers' adoption of improved yam storage methods (Osagie 1992). It was hoped that farmers' adoption of these technologies would lead to food losses, improved income and enhanced food security (Florkowski and Xi-Ling 1990).

However, the widespread and continued use of traditional storage practices by small scale and subsistence farmers in Edo State despite considerable losses usually associated with these methods (Mughogho 1989) and the availability of improved storage methods (Osagie1992) warrant investigation.

\section{Objectives of the Study}

The study examined the factors affecting the adoption of yam storage technologies by farmers in the northern ecological zone of Edo State, Nigeria. Specifically, this study looked at the following objectives, which are to:

1. Identify the personal characteristics of yam producers in the study area.

2. Ascertain the yam storage methods the farmers are presently using.

3. Assess the farmers' awareness and adoption of improved yam storage methods recommended by the state extension service.

4. Determine the factors affecting the adoption of these improved storage methods by the farmers.

5. Ascertain the seriousness of post-harvest losses and identify the yam storage problems faced by farmers in the study area.

\section{Hypothesis of the Study}

The following null hypothesis was tested:

Ho: There is no significant association between farmers' socio-economic characteristics and adoption of improved yam storage techniques.

\section{METHODOLOGY}

The northern ecological zone of Edo State is characterized by savannah vegetation, and lies within the northern agricultural zone of the state agricultural extension service. Farming is the predominant economic activity of the people yam, maize and cassava are major crops grown.
The zone comprises of 5 Local Government (LGAs) councils namely Owan West, Owan East, Etsako Central, Etsako West and Akoko - Edo. Owan West and Etsako West LGs were randomly sampled. Owan West consists of 9 communities (Sabo, Ukhomora, Emen, Okhia, Ovbiokhuan, Oke, Abiosi, Uzeba and Okpuje) of which 3 communities (Abiosi, Oke and Uzeba) were randomly sampled. In Etsako West LG, 3 communities were also randomly sampled (Ayoywiri, Usogun and Agbede) from a total of 10 (Fuga, Agbede, Ekperi, Udaba, Ayoywiri, Azukara, Ogomeri, Usogun, Ugbekpe, Anegbete). From each selected community (6 in all) 25 yam farmers were randomly sampled, making the total respondents 150 .

Data were gathered from the respondents by means of a structured interview schedule. Only 127 of the expected 150 responses were found useful for data analysis. Analysis of data was done using frequency table, percentage, mean and logistic regresson.

\section{Measurement of Variables}

Adoption of Improved Storage Technologies: For the purpose of hypothesis test, a farmer is taken to be an adopter if he/she is using any of the recommended storage method.

Yam Storage Constraints: The seriousness of specific post-harvest storage problems of the farmers was measured on a 5 point Likert scale: very serious (scored 5), serious (4), moderately serious (3), not serious (2) and undecided (1). To decide which constraints were serious, a mean score of 3.00 was used as in Tologbonse et al (2006). This mid-point was obtained by summing the assigned scores $(1+2+3+4+5)$ to get 15 and dividing by 5 to get 3.00 . The weighted mean score for each problem was obtained by multiplying the frequency scores with the point scale for each rating and dividing by the sample size (number of respondents). Any variable/storage problem having a mean score $\geq 3.00$ is considered serious while any with a weighted mean score $<3.00$ is considered not serious.

\section{RESULTS AND DISCUSSION}

\section{Personal Characteristics of Respondents}

Results of Table 1 show that yam production in the study area is male dominated (94.5\%), which 
may be attributed to the intensive labour requirement of yam cultivation (e.g. heap construction, pegging and digging). Most respondents were married (83.5\%) while more than half $(60.6 \%)$ had a low educational experience not exceeding primary education, which may impede their acceptance of improved storage technologies since education facilitates farmers' adoption of innovations (Onemolease 2005).

Most respondents were above 40 years $(81.16 \%)$ indicating an ageing farming population, which is consistent with the assertions of Ekong (2003) that farming in the rural areas of Nigeria is dominated by older farmers because of the outmigration of youths to urban centres in search of white-collar jobs. The farmers are quite experienced in yam cultivation since the majority of them $(45.6 \%)$ have been cultivation the crop for over 20 years. About 52\% of them have 5-9

Tale 1: Personal characteristics of respondents (n = 127)

\begin{tabular}{|c|c|c|}
\hline Variables & Frequency & Percentages \\
\hline \multicolumn{3}{|l|}{ Gender } \\
\hline Female & 7 & 5.5 \\
\hline Male & 120 & 94.5 \\
\hline \multicolumn{3}{|l|}{ Marital Status } \\
\hline Married & 106 & 83.5 \\
\hline Single & 21 & 16.5 \\
\hline \multicolumn{3}{|l|}{ Educational Level } \\
\hline Did not go to school & 24 & 18.9 \\
\hline Primary school & 53 & 41.7 \\
\hline Secondary school & 41 & 32.3 \\
\hline Post - secondary education & 9 & 7.1 \\
\hline \multicolumn{3}{|l|}{ Age (years) } \\
\hline 30 and below & 3 & 2.4 \\
\hline $31-40$ & 47 & 36.5 \\
\hline $41-50$ & 63 & 49.6 \\
\hline $51 \&$ above & 40 & 31.5 \\
\hline \multicolumn{3}{|l|}{ Farming Experience (years) } \\
\hline $10 \&$ below & 30 & 23.7 \\
\hline $11-20$ & 39 & 30.7 \\
\hline $21 \&$ above & 58 & 45.6 \\
\hline \multicolumn{3}{|l|}{ Household Size } \\
\hline 4 \& below & 17 & 13.4 \\
\hline $5-9$ & 66 & 52.0 \\
\hline $10-14$ & 32 & 25.2 \\
\hline Above 14 & 12 & 9.4 \\
\hline \multicolumn{3}{|l|}{ Farm Size (hectare) } \\
\hline $1.0 \&$ below & 86 & 67.7 \\
\hline $1.1-2.0$ & 24 & 18.9 \\
\hline $2.1 \&$ above & 17 & 13.4 \\
\hline \multicolumn{3}{|l|}{ Income $(\mathbb{N}) *$} \\
\hline $20,000 \&$ below & 24 & 18.9 \\
\hline $20,001-40,000$ & 55 & 43.3 \\
\hline $40,001-60,000$ & 26 & 20.5 \\
\hline$>60,000$ & 22 & 17.3 \\
\hline
\end{tabular}

*Exchange rate: 1US Dollar to 136 Naira Source: Field survey, 2006 members in their household, implying that they have access to costless labour thereby reducing labour cost.

The small operational scale of the farmers (67.7\% had 1ha and below) may limit output and constrain adoption of modern storage facilities (Bhattacharyya 1997). The economic return to yam production in the study area is very low: only $43.3 \%$ realized an annual income of 20,001-40,000 naira (147.05 - 294.11 US dollars). The finding suggests that the farmers produced other crops, as confirmed by the researchers' observation of the farming system in the study area, which is characterized by mixed cropping.

\section{Traditional Storage Methods Used by Respondents}

Table 2 reveals the major traditional storage method used by the respondents and the frequency or regularity of use. The result indicates that storage of yam tubers in barns was the major storage method used by the respondents in the study area (100\%). However, in terms of frequency of use, yam barns (mean = 4.87) and heaping of yam tubers and covering them on the floor with grass/soil $($ mean $=3.69)$ were regularly used as storage methods by the respondents. These methods have been criticized of been an ineffective and inefficient method of storage (Mughogho 1989).

Table 2: Traditional storage methods of respondents

\begin{tabular}{lccc}
\hline Methods & \multicolumn{2}{c}{$\begin{array}{c}\text { Major method } \\
\text { used }\end{array}$} & $\begin{array}{c}\text { Regularity } \\
\text { (Mean) }\end{array}$ \\
\cline { 2 - 3 } & Freq & $\%$ & \\
\hline Yam barns & 127 & 100.00 & $4.87^{*}$ \\
Heaping and covering & - & - & $3.69^{*}$ \\
$\quad$ of yam tubers & & & \\
Bare floor/ground & - & - & 1.91 \\
Raised platform & - & - & 1.54 \\
Pits/holes dug in ground & - & - & 1.51 \\
\hline
\end{tabular}

* Regular (mean > 3.50)

Source: Field survey, 2006

\section{Respondents' Perception of Storage Losses}

The result of Table 3 shows that $44.1 \%$ of the respondents experienced serious post-harvest storage losses, $21.3 \%$ suffered very serious losses while $34.6 \%$ considered the losses not serious. The finding shows that majority of the yam 
Table 3: Respondents' perception of storage losses

\begin{tabular}{lcc}
\hline Perception & Frequency & $\%$ \\
\hline Not serious & 44 & 34.6 \\
Serious & 56 & 44.1 \\
Very serious & 27 & 21.3 \\
\hline Total & 127 & 100.0 \\
\hline
\end{tabular}

Source: Field survey, 2006

producers encountered severe post-harvest storage losses, and this calls for serious concern.

\section{Storage Problems Faced by Respondents}

From Table 4, it is seen that tuber rottening, with a mean of 3.56 , was the only serous storage problem faced by the respondents. Others such as rodent attack (3.17), infection of tubers (2.39) and insect/termite attack (2.25) were not considered serous $($ mean $<3.50)$.

Table 4: Storage problems faced by respondents

\begin{tabular}{ll}
\hline Problems & Mean \\
\hline Rottening of tubers & $3.56^{*}$ \\
Rodent attack & 3.17 \\
Infection of tubers & 2.39 \\
Insect/termite attack & 2.25 \\
Theft of tubers & 2.10 \\
\hline
\end{tabular}

*Serious (mean > 3.50)

Source: Field survey, 2006

\section{Respondent Awareness and Adoption of Improved Storage Methods}

Results of Table 5 indicate that none of the respondents were aware of or adopted refrigeration and gamma irradiation as a yam storage method. About $26.8 \%$ were aware of the use of chemicals in yam storage but only $11 \%$ have adopted it, and while $30.7 \%$ were aware of shelving (i.e. storing in barns having shelves on which yams can be placed), only $28.3 \%$ have adopted it. The result shows that the awareness and adoption of improved yam storage methods by farmers in the study area are low, with shelving being the most widely adopted method.

\section{Respondent Classification Based on Use of Improved Storage Methods}

Table 6 reveals that the majority of the respondents $(66.9 \%)$ did not adopt any of the improved yam storage methods while $33.1 \%$ have adopted at least one of the methods. The result indicates that the level of adoption was very poor in the study area, and probably explains the seriousness of post-harvest storage losses experienced by the farmers (see Table 3 )

Table 6: Respondent classification based on use of improved storage methods.

\begin{tabular}{lcc}
\hline Category & Frequency & Percentage \\
\hline Non - adopter & 85 & 66.9 \\
Adopter & 42 & 33.1 \\
\hline Total & 127 & 100.0 \\
\hline Source: Field survey, 2006 &
\end{tabular}

\section{Factors Responsible for Respondents' Non - Use of Improved Storage Methods}

The result of Table 7 reveals that ignorance of existence of storage methods (100\%), non availability $(46.5 \%)$ and high cost $(34.6 \%)$ of storage technologies accounted for farmers nonuse of modern storage technologies, while about $20 \%$ claimed not to understand their use. The percentage of non - response was high because respondents felt they could not explain their non - adoption for technologies whose existence they are not aware of such as refrigeration and irradiation. Thus, all (100\%) claimed ignorance of existence.

Table 5: Respondent awareness and adoption of improved storage methods $(n=127)$

\begin{tabular}{|c|c|c|c|c|}
\hline \multirow[t]{2}{*}{ Modern methods } & \multicolumn{2}{|c|}{ Awareness } & \multicolumn{2}{|c|}{ Adoption } \\
\hline & Freq * & $\%$ & Freq * & $\%$ \\
\hline Refrigeration (i.e. use of fridge/deep freezer) & - & - & - & - \\
\hline Gamma irradiation & - & - & - & - \\
\hline $\begin{array}{l}\text { Shelving (i.e. string in barns having shelves on } \\
\text { which yams can be placed). }\end{array}$ & 39 & 30.7 & 36 & 28.3 \\
\hline Use of chemicals (inhibit sprouting/prevent root rot) & 34 & 26.8 & 14 & 11.0 \\
\hline
\end{tabular}

* Multiple response

Source: Field survey, 2006 
Table 7: Factors responsible for farmers non - use of improved storage methods

\begin{tabular}{|c|c|c|c|c|c|c|}
\hline \multirow[t]{2}{*}{ Factors } & \multicolumn{2}{|c|}{ Serious } & \multicolumn{2}{|c|}{ Not serious } & \multicolumn{2}{|c|}{ Non response } \\
\hline & Freq * & $\%$ & Freq* & $\%$ & Freq * & $\%$ \\
\hline Ignorance of existence & 127 & 100.0 & - & - & - & - \\
\hline Non - available of technology & 59 & 46.5 & 12 & 9.4 & 56 & 44.1 \\
\hline High cost of methods & 44 & 34.6 & 29 & 22.8 & 54 & 42.5 \\
\hline Do not understand how to use it & 25 & 19.7 & 36 & 28.3 & 66 & 52.0 \\
\hline
\end{tabular}

* Multiple response hence total exceed sample size (127)

Source: Field survey, 2006

\section{Relationship Between Farmers' Characteristics and Adoption of Improved Storage Methods by Farmers (Logistic Regression)}

Table 8 shows that a significant $(\mathrm{p}<0.05)$ association exist between farmers age (Odd ratio $=0.67$ ), farming experience (1.25), farm size (3.68), contact with extension agents (1.79) and adoption of improved yam storage technology. The R square $(0.683)$ shows that about $68 \%$ of the odd/ likelihood of farmers adopting improved storage technology is explained by the independent variables with a percent prediction of $92 \%$. The significance of the model is given by the model chi-square $(85.56 ; \mathrm{p}<0.05)$.

Older farmers were 0.67 times less likely to adopt improved storage methods compared with younger farmers, corroborating the finding of Lemchi et al. (2003) that younger farmers are more likely to adopt farm innovations than the older farmers being more willing to take risk. Farmers with longer farming experience are 1.3 times more likely to adopt improved storage technology compared with the less experienced farmers. Onemolease (2005) obtained a significant negative

Table 8: Relationship between farmers' characteristics and adoption of improved storage method (Logistic regression)

\begin{tabular}{lcc}
\hline Variables & $\begin{array}{c}\text { Odds ratio } \\
(\text { OR })\end{array}$ & $\begin{array}{c}\text { Prob. } \\
\text { level }\end{array}$ \\
\hline Sex & 0.001 & 0.683 \\
Education & 1.18 & 0.683 \\
Age & $0.67 *$ & 0.000 \\
Farming experience & $1.25^{*}$ & 0.000 \\
Household size & 1.133 & 0.243 \\
Farm size & $3.68 *$ & 0.005 \\
Income & 0.82 & 0.503 \\
Contact with extension agents & $1.79 *$ & 0.044 \\
Model Estimates & & \\
$\quad \%$ correct prediction & 92.1 & \\
$\quad$ Nagelkerke R Square & 0.682 & \\
Model Chi-square & 85.56 & \\
\hline
\end{tabular}

Source: Computed from field Survey data, 2006. relationship between farming experience and adoption of technologies. Farmers with large farms are almost 4 times as likely as their farmers with smaller farms to adopt improved storage technology. Farmers with larger farms have been reported to be positively disposed to use of farm innovations (Agbamu 1993), largely because having larger farms strengthens farmers capacity to produce more, which he/she would be interested in preserving from loss. Farmers' in contact with extension agents are almost 2 times (odd ratio $=1.78$ ) as likely as those with no contact to adopt improved storage technology. The result agrees with the findings of Atala et al. (1992). Extension agents, by interacting with farmers, are able to convince them to implement recommended farm innovations.

\section{CONCLUSION AND RECOMMENDATIONS}

The results of the study indicated that yam farmers in the study area experienced serious postharvest yam storage losses particularly due to tuber rot. Despite the dissemination of improved storage methods most farmers claimed not to be aware and are yet to adopt the technologies. Reasons for the low adoption was, apart from lack of awareness of the storage methods, include non - availability and high cost of the storage technologies in addition to a poor understanding of technology utilization (19.7\%).

To facilitate the adoption of modern postharvest yam storage technologies among farmers in the study area, the following recommendations are proposed:

Extension agents should actively disseminate information on improved storage techniques to yam farmers in the study area through use of mass media (e.g. radio/tv) and farmers groups.

To solve the problem of inadequate capital, farmers should pool their funds through joint contribution. Such funds can be used to purchase the costly storage facilities. 
Available sources of storage technologies should be communicated to farmers by the zonal extension service.

Use of some modern storage technologies require specialised skills and technical know-how which farmers lack. Farmers should be trained on the use of these improved storage methods such as chemicals and refrigeration.

\section{REFERENCES}

Agbamu JU 1993. Analysis of Farmers Characteristics Associated with Adoption of Soil Management Innovations in Ikorodu Local Government Area of Lagos state Nigeria Journal of Rural Extension and Development, 1(2): $51-67$.

AMCOST 2006. Technologies to reduce post-harvest food loss The African Ministerial Council on Science and Technology (AMCOST) of the African Union (AU), Pretoria, South Africa, (2006). From <http:/ /www.nepadst.org/platforms/foodloss.shtml> (Retrieved August 17, 2006).

Atala TK Akanya EE, Abdullahi YA 1992. Adoption of Recommended Horticultural Practices in Kano LGA of Kano State of Nigeria. The Nigerian Journal of Rural and Community Development, 4: $70-80$.

Bhattacharyya A,Veserat W 1997. Factors influencing rates of adoption of T. Vaccine by Nevadeane cattle producers. Journal of Agricultural and Resource Economics, 22 (1): 174 - 190.

Ekong EE 2003. An Introduction to Rural Sociology Uyo: Dove Educational Publications, pp. 25-26, 270

Ezeike GOI 1995. Successful introduction of improved yam storage methods for Nigerian farmers. Proceeding of the Workshop on the 'African Experience on Post-harvest Technology Develop-ment', Accra (Ghana), $4-8$ July 1994. Rome: FAO.

FAO 1998. Storage and Processing of Roots and Tubers in the Tropics. The Food and Agricultural Organisation (FAO), Rome . From <http://www.fao.org/ documents/show_cdr.asp?url_file=/docrep/X5415E/ X5415E00.htm> (Retrieved August 17, 2006)

FAO, UNEP 1981. Food loss prevention in perishable crops. From <http://www.fao.org/documents/ show_cdr.asp?url_file $=/$ docrep/S8620E/ S8620E $09 . h t m>$ (Retrieved August 17, 2006)

Fiagan YS 1995. Amélioration du stockage et de la conservation. Des ignames. Evaluation technique et économique: Expérience du Bénin. Paper presented in Workshop on the African Experience on Postharvest Technology Development, Accra (Ghana), 4-8 July 1994, pp. 25-39

Florkowski J, Xi-Ling W 1990. Simulating the impact of pecan storage technology on farm price and grower's income. Southern Journal of Agricultural Economics, 22(2): 217 - 222.

Knoth J 1993. Traditional Storage of Yams and Cassava and its Improvements. Germany: GTZ, 49 p.
Lemchi J 2003. Tshiunza, M.and Tenkouano, A.: Factors driving the intensity and rate of cooking banana adoption on Nigeria Journal of Agriculture and Social Research, 3(2): 135 - 166

Mughogho MJK 1989. Malawi: Food security issues and challenge for 1990's. In: M Rukuni (Ed.): Food Security Policies in the SADC Region. Harare. University of Zimbabwe and Michigan State University Food Security Research in Southern Africa Project. Department of Agricultural Economics and Extension.

Onemolease EA, Aghanenu AS, Adisa T 2001. Effect of formal school education on farmers output and adoption of innovations: A case study of rubber farmers in Ikpoba-Okha local government area of Edo State. Journal of Teacher Education and Teaching, 5(1): $114-118$.

Onemolease EA 2005. Impact of the Agricultural Development Programme (ADP) Activities in Arable Crop Production on Rural Poverty Alleviation in Edo State, Nigeria. Ph.D Thesis (Unpublished), University of Benin, Benin City, Edo State, Nigeria p123

Omoruyi SA Orhue UX Ake-obo AA, Akhimien CI 1995. Prescribed agricultural science for senior secondary schools, Benin City: Idodo Umeh Publications Limited, pp. 4 - 6

Orraca-Tetteh R 1978. Post-harvest physiology and storage of Nigerian crops Food and Nutrition Bulletin, 1(1). The United Nations University Press, Tokyo, Japan.. From <http://www.unu.edu/unupress/ food/8F011e/8F011E0a.htm> (Retrieved August 21, 2006)

Osagie AU 1992. The Yam Tuber in Storage. Poshharvest Research Unit, University of Benin, Benin City, pp. 11-21, 157-173, 196

Takavarasha T, Rukovo A 1989. Food security issues and challenges for the 1990's. In: M Rukuni (Ed.): Food Security Policies in the SADC Region. Harare. University of Zimbabwe and Michigan State University Food Security Research in Southern Africa Project. Department of Agricultural Economics and Extension.

Thamaga-Chitja JM, Hendriks SL, Ortmann GF, Green M 2004. Impact of maize storage on rural household food security in Northern Kwazulu-Natal Tydskrif vir Gesinsekologie en Verbruikerswetenskappe, 32: 8-15 From <http://www.up.ac.za/academic/acadorgs/ saafecs/vol32/chitja.pdf> (Retrieved August 27, 2006)

Tologbonse EB Mesini O, Tsaso JH 2006. Farmers perception of sources of information in relation to adoption of improved rice technology by farmers in the inland valley swaqmps of middle-belt zone of Nigeria Journal of Agricultural Extension, 9: 63-73.

Tyler PS 1982. Misconception of food losses Food and Nutrition Bulletin 4(2), The United Nations University Press, From <http://www.unu.edu/ unupress/food/8F042e/8F042E05.htm> (Retrieved August 27, 2006). 